\title{
Systemic Epstein-Barr virus-positive T-cell lymphoproliferative disease of childhood: Report of a case with review of the literature
}

\author{
MIYUKI YOSHII $^{*}$, MITSUAKI ISHIDA ${ }^{1,2^{*}}$, KEIKO HODOHARA $^{3}$, HIROKO OKUNO $^{1}$, \\ RYOTA NAKANISHI $^{1}$, TAKASHI YOSHIDA ${ }^{1}$ and HIDETOSHI OKABE ${ }^{1,2}$ \\ ${ }^{1}$ Department of Clinical Laboratory Medicine, ${ }^{2}$ Division of Diagnostic Pathology and ${ }^{3}$ Department of Hematology, \\ Shiga University of Medical Science, Otsu, Shiga 520-2192, Japan
}

Received February 20, 2012; Accepted May 31, 2012

DOI: $10.3892 / \mathrm{ol} .2012 .754$

\begin{abstract}
Systemic Epstein-Barr virus (EBV)-positive T-cell lymphoproliferative disease (LPD) of childhood is an extremely rare and distinct clinicopathological entity. The majority of these cases occur with an apparent primary EBV infection. In this study, we describe a case of systemic EBV-positive T-cell LPD of childhood in a 23-year-old female with primary EBV infection, and review the clinicopathological features of this disease. A 23-year-old previously healthy female without an immunocompromized status presented with an acute onset of high fever. Laboratory examinations revealed a markedly elevated white blood cell count and liver and renal function. Peripheral blood smears identified a number of atypical lymphocytes with small azurophilic granules in the cytoplasm. Bone marrow aspiration revealed marked proliferation of small-sized lymphocytes with convoluted nuclei, which expressed EBER1, CD3, CD8 and cytotoxic granules. Monoclonal rearrangements of T-cell receptors were also detected. The patient underwent chemotherapy, but succumbed to multiorgan failure 20 weeks after administration. Upon review of 17 cases of this disease, including the one in the present study, we identified that the major clinicopathological features of systemic EBV-positive T-cell LPD of childhood are as follows: i) clonal systemic proliferation of EBV-infected T-cells that appear morphologically innocuous with an activated cytotoxic phenotype; ii) a high prevalence in the Asian population, commonly affecting children and young adults; iii) a predilection for males; iv) most commonly involved sites are the liver, spleen, lymph node and bone marrow, and the main clinical presentations are hepatosplenomegaly, fever and pancytopenia; v) almost all cases have an aggressive clinical
\end{abstract}

Correspondence to: Dr Mitsuaki Ishida, Department of Clinical Laboratory Medicine and Division of Diagnostic Pathology, Shiga University of Medical Science, Tsukinowa-cho, Seta, Otsu, Shiga 520-2192, Japan

E-mail: mitsuaki@belle.shiga-med.ac.jp

*Contributed equally

Key words: lymphoproliferative disease, Epstein-Barr virus, T-cell course, which results in mortality. Cytological atypia of the neoplastic cells in this disease, as observed in the present case, is minimal. This study revealed that the cytomorphological features of atypical lymphocytes in the peripheral blood are indistinguishable from those of infectious mononucleosis.

\section{Introduction}

Systemic Epstein-Barr virus (EBV)-positive T-cell lymphoproliferative disease (LPD) of childhood is an extremely rare and distinct clinicopathological entity, which has recently been categorized into the spectrum of EBV-related T-cell lymphoproliferative disorders of childhood according to the World Health Organization (WHO) classification (1). The majority of these cases usually occur with an apparent primary EBV infection, but may occasionally be associated with severe chronic active EBV infection in children or young adults, with an aggressive clinical course (1-3). In this study, we describe a case of systemic EBV-positive T-cell LPD in a 23-year-old female with primary EBV infection. We identify the cytological features of the peripheral blood and review the clinicopathological features of this disease.

\section{Case report}

A previously healthy 23-year-old female without an immunocompromised status presented with an acute onset of high fever at an outpatient clinic. Laboratory examinations revealed a number of atypical lymphocytes within the peripheral blood, elevated liver and renal function and disseminated intravascular coagulation syndrome. The patient was referred to the Department of Hematology at Shiga University of Medical Science, Shiga, Japan. This study was approved by the Ethics Committee at Shiga University of Medical Science. Informed consent was obtained from the patient prior to the study.

A physical examination revealed hepatosplenomegaly, hemorrhage in the bilateral conjunctiva, mild lymphadenopathy of the cervical lymph nodes, and pleural effusion and ascites. Laboratory examinations demonstrated markedly elevated white blood cells $(61,800$ cells $/ \mu 1$; range, $3,000-8,000)$, activated partial thromboplastin time (91.9 sec; range, 25-40), D-dimer $(68.8 \mu \mathrm{g} / \mathrm{ml} ;<1.0)$, aspartate aminotransferase $(11,376 \mathrm{U} / 1$; range, 13-33), alanine aminotransferase (2,254 U/1; range, 
6-27), lactate dehydrogenase (19,179 U/1; range, 119-229), blood urea nitrogen $(65.2 \mathrm{mg} / \mathrm{dl}$; range, $8-22)$, creatinine $(3.37 \mathrm{mg} / \mathrm{dl}$; range, 0.4-0.7) and soluble IL-2 receptor levels $(51,500 \mathrm{U} / \mathrm{ml}$; range, 124-466). The patient's red blood cell count $\left(4.39 \times 10^{4}\right.$ cells $/ \mu 1$; range, 3.8-4.8) was within the normal range, while the platelet concentration was decreased $\left(64 \times 10^{3}\right.$ platelets $/ \mu 1$; range, 150-400). Additionally, the patient's EBV-anti-VCA-IgG antibody titer was increased 160 -fold, and anti-VCA-IgM, anti-VCA-IgA, anti-EA-DR-IgG, anti-EA-DR-IgA and anti-EBNA antibody titers were less than 10-fold. EBV-DNA was detected at $2.8 \times 10^{6}$ copies $/ 10^{6}$ cells in the patient's serum.

Peripheral blood smears stained with Giemsa were taken. These demonstrated a number of atypical lymphocytes, which had large irregular-shaped nuclei with lobated and moderately coarse chromatin and inconspicuous nucleoli. They also revealed an abundant radial or peripheral basophilic cytoplasm with small azurophilic granules (Fig. 1). Flow cytometry of the peripheral blood demonstrated a marked increase $(96 \%)$ of

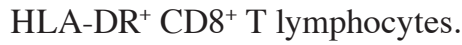

Formalin-fixed,paraffin-embedded tissue blocks of the bone marrow and liver were cut into $3-\mu \mathrm{m}$ sections, deparaffinized and rehydrated. Each section was stained with hematoxylin and eosin (H\&E) and then used for immunostaining and in situ hybridization. Immunostaining and in situ hybridization were conducted using an autostainer (BenchMark XT system; Ventana Medical System Inc., Tucson, AZ, USA) according to the manufacturer's instructions. The primary antibodies used were: rabbit monoclonal antibody against CD4 (SP35; Ventana Medical Systems Inc.) and mouse monoclonal antibodies against $\beta$ F1 (8A3; Thermo Scientific, Waltham, MA, USA), CD3 (PS1; Novocastra Laboratories, Ltd., Newcastle upon Tyne, UK), CD8 (1A5; Novocastra Laboratories), CD20 (L26; Novocastra Laboratories), CD56 (CD564; Novocastra Laboratories), granzyme B (11F; Novocastra Laboratories) and TIA-1 (TIA-1; GeneTex Inc., Irvine, CA, USA). For in situ hybridization, an INFORM EBV-encoded small RNA (EBER) 1 probe (Ventana Medical Systems Inc.) was used.

Bone marrow aspiration revealed marked proliferation of small-sized lymphocytes with slightly enlarged and convoluted nuclei, inconspicuous nucleoli (Fig. 2A) and hemophagocytosis. In situ hybridization for EBV using the EBER1 probe demonstrated marked positivity in the majority of small-sized lymphocytes. Double staining for EBER1 and CD3 or CD8 revealed that these small lymphocytes expressed both EBER1 and CD3 or CD8 (Fig. 2B). Furthermore, these lymphocytes also expressed $\beta$ F1, granzyme B and TIA-1, but were negative for CD4 and CD56.

A liver biopsy demonstrated proliferation of small-sized lymphocytes in the portal area with sinusoidal infiltration (Fig. 2C); these lymphocytes were positive for CD3, CD8, $\beta$ F1, granzyme B, TIA-1 and EBER1.

An analysis of T-cell receptor (TCR) gene rearrangement was conducted using southern blot analysis. The results demonstrated monoclonal rearrangements of the TCR $\beta$ chain $\mathrm{C} \beta$ and $\gamma$ chain $\mathrm{J} \gamma$ regions. EBV DNA was also detected in the atypical lymphocytes of the peripheral blood. Subsequently, an ultimate diagnosis of systemic EBV-positive T-cell LPD of childhood was confirmed.

The patient underwent continuous hemodiafiltration, and was initially administered etoposide, cyclosporine and

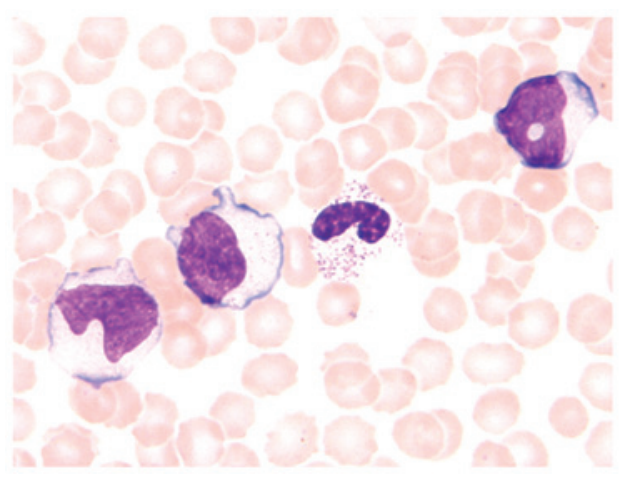

Figure 1. Atypical lymphocytes in the peripheral blood stained with Giemsa. Atypical lymphocytes have irregular-shaped large nuclei with coarse chromatin and basophilic cytoplasm with small azurophilic granules (magnification, $\mathrm{x} 400$ ).

A

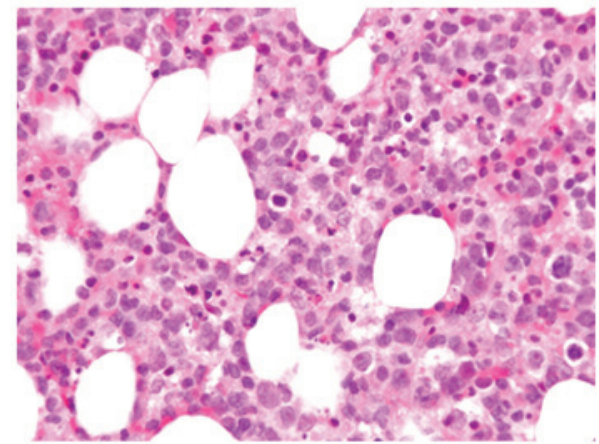

B

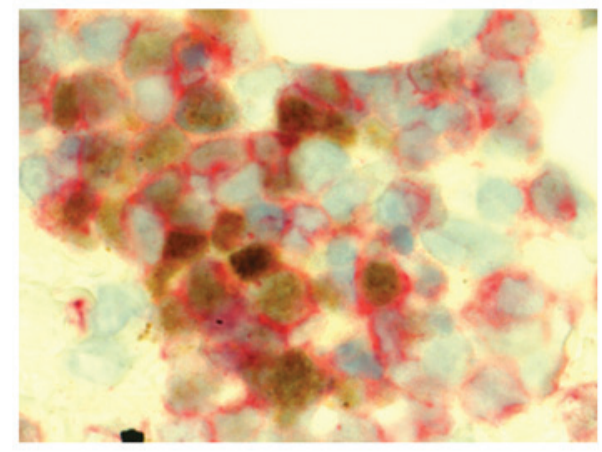

C

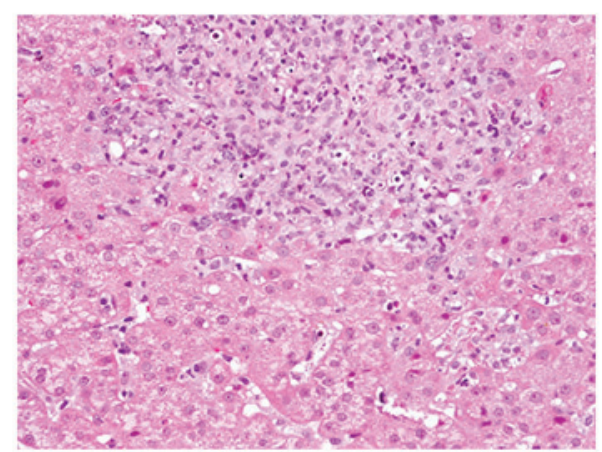

Figure 2. Results of bone marrow and liver biopsy. (A) Marked proliferation of small-sized lymphocytes with minimal atypia in the bone marrow (H\&E staining; magnification, x200). (B) Lymphocytes in the bone marrow expressing both EBER1 and CD8 (EBER1, brown; CD8, red) (magnification, $\mathrm{x} 400)$. (C) Proliferation of small-sized lymphocytes in the portal area of the liver (H\&E staining; magnification, x200). H\&E, hematoxylin and eosin; EBER1, EBV-encoded small RNA 1 
Table I. Clinicopathological features of systemic EBV-positive T-cell LPD following primary EBV infection.

\begin{tabular}{|c|c|c|c|c|c|c|c|c|}
\hline $\begin{array}{l}\text { Case } \\
\text { No. }\end{array}$ & $\begin{array}{c}\text { Age } \\
\text { (years) }\end{array}$ & Gender & $\begin{array}{l}\text { Ethnic } \\
\text { origin }\end{array}$ & Clinical presentation & Phenotype & $\begin{array}{l}\text { TCR } \\
\text { status }\end{array}$ & Outcome & Refs. \\
\hline 1 & 13 & M & Asian & $\begin{array}{l}\text { Fever, hepatosplenomegaly, } \\
\text { jaundice, lymphadenopathy }\end{array}$ & $\mathrm{CD}^{+}$ & $\beta R$ & DOD & 4 \\
\hline 2 & 7 & M & Asian & $\begin{array}{l}\text { Fever, hepatosplenomegaly, } \\
\text { lymphadenopathy }\end{array}$ & $\mathrm{CD}^{+}$ & $\beta R$ & DOD & 4 \\
\hline 3 & 2 & M & Asian & $\begin{array}{l}\text { IM followed by hepatic failure, } \\
\text { pancytopenia, sepsis }\end{array}$ & $\mathrm{CD}^{+}$ & NA & DOD & 5 \\
\hline 4 & 16 & $\mathrm{~F}$ & NA & $\begin{array}{l}\text { IM followed by fever, } \\
\text { lymphadenopathy, VAHS }\end{array}$ & $\mathrm{CD}^{+}$ & $\begin{array}{c}\beta \text { and } \\
\gamma \mathrm{R}\end{array}$ & DOD & 6 \\
\hline 5 & 3 & $\mathrm{~F}$ & Asian & $\begin{array}{l}\text { Fever, hepatosplenomegaly, } \\
\text { lymphadenopathy }\end{array}$ & $\mathrm{CD}^{+}$ & $\beta R$ & DOD & 7 \\
\hline 6 & 20 months & $\mathrm{F}$ & NA & $\begin{array}{l}\text { Fever, hepatosplenomegaly, } \\
\text { skin rash }\end{array}$ & NA & $\beta R$ & DOD & 8 \\
\hline 7 & 1 & M & Asian & $\begin{array}{l}\text { Fever, hepatosplenomegaly, } \\
\text { lymphadenopathy }\end{array}$ & $\mathrm{CD}^{+}$ & NA & DOD & 9 \\
\hline 8 & 1 & $\mathrm{~F}$ & Asian & $\begin{array}{l}\text { Fever, hepatosplenomegaly, } \\
\text { pancytopenia }\end{array}$ & $\begin{array}{c}\mathrm{CD}^{+} \\
\text {and } \mathrm{CD}^{+}\end{array}$ & $\begin{array}{c}\beta \text { and } \\
\gamma \mathrm{R}\end{array}$ & $\begin{array}{l}\text { Relapse } \\
15 \text { months }\end{array}$ & 10 \\
\hline 9 & 5 & M & Asian & $\begin{array}{l}\text { Fever, hepatosplenomegaly, } \\
\text { pancytopenia, VAHS }\end{array}$ & NA & $\begin{array}{l}\beta \text { and } \\
\gamma G\end{array}$ & DOD & 11 \\
\hline 10 & 1 & M & Asian & $\begin{array}{l}\text { Fever, hepatosplenomegaly, } \\
\text { pancytopenia, VAHS }\end{array}$ & NA & $\begin{array}{l}\beta \text { and } \\
\gamma \mathrm{G}\end{array}$ & DOD & 11 \\
\hline 11 & 37 & M & Caucasian & $\begin{array}{l}\text { Fever, hepatosplenomegaly, } \\
\text { jaundice, pancytopenia }\end{array}$ & $\mathrm{CD}^{+}$ & $\gamma \mathrm{R}$ & DOD & 2 \\
\hline 12 & 17 & M & Mexican & $\begin{array}{l}\text { Hepatosplenomegaly, symptoms } \\
\text { of upper respiratory infection, } \\
\text { jaundice, pancytopenia }\end{array}$ & $\mathrm{CD}^{+}$ & $\gamma \mathrm{R}$ & DOD & 2 \\
\hline 13 & 23 & M & Asian & $\begin{array}{l}\text { Fever, hepatosplenomegaly, } \\
\text { jaundice, pancytopenia, } \\
\text { lymphadenopathy }\end{array}$ & $\begin{array}{c}\mathrm{CD}^{+} \\
\text {and } \mathrm{CD}^{+}\end{array}$ & $\gamma \mathrm{R}$ & DOD & 2 \\
\hline 14 & 22 & $\mathrm{~F}$ & Mexican & $\begin{array}{l}\text { Fever, hepatosplenomegaly, } \\
\text { jaundice }\end{array}$ & $\mathrm{CD}^{+}$ & $\gamma \mathrm{G}$ & NA & 2 \\
\hline 15 & 27 months & M & Mexican & $\begin{array}{l}\text { Fever, hepatosplenomegaly, } \\
\text { skin rash, pancytopenia }\end{array}$ & $\mathrm{CD}^{+}$ & $\gamma \mathrm{R}$ & DOD & 2 \\
\hline 16 & 45 & M & Asian & Diarrhea, weight loss & NA & $\gamma \mathrm{G}$ & DOD & 12 \\
\hline $\begin{array}{l}\text { Present } \\
\text { case }\end{array}$ & 23 & $\mathrm{~F}$ & Asian & $\begin{array}{l}\text { Fever, hepatosplenomegaly, } \\
\text { DIC, liver and renal failure }\end{array}$ & $\mathrm{CD}^{+}$ & $\begin{array}{c}\beta \text { and } \\
\gamma \mathrm{R}\end{array}$ & DOD & \\
\hline
\end{tabular}

EBV, Epstein-Barr virus; LPD, lymphoproliferative disease. TCR, T-cell receptor ; G, germline; R, rearranged. NA, not available; IM, infectious mononucleosis; VAHS, virus-associated hemophagocytic syndrome; DIC, disseminated intravascular coagulation; DOD, dead of disease.

prednisolone, followed by cyclophosphamide, hydroxydaunorubicin, oncovin and prednisolone (CHOP) therapy. The patient succumbed to multiorgan failure 20 weeks after chemotherapy.

\section{Discussion}

More than $90 \%$ of EBV-associated LPD is of B-cell origin and occurs in the setting of immunosuppression or following an organ transplant. However, EBV may also infect T lympho- cytes. Two major types of EBV-positive T-cell LPDs of childhood have been defined by WHO classification. The first is systemic EBV-positive T-cell LPD of childhood, and the second is hydroa vacciniforme-like lymphoma demonstrating an indolent clinical course $(1,2)$. Systemic EBV-positive T-cell LPD of childhood following acute EBV infection is extremely rare. The majority of previous studies have reported single cases; however, the study by Quintanilla-Martinez et al described the clinicopathological features of 5 cases of this disease (2). In this study, we reviewed the clinicopatho- 
logical features of 17 cases with systemic EBV-positive T-cell LPD of childhood following acute EBV infection, including the present case (Table I) (2,4-12). We revealed that clonal systemic proliferation of EBV-infected T-cells that appear morphologically innocuous with an activated cytotoxic phenotype expressing CD8 and/or CD4 is central to the disease. We also identified that there is a high prevalence in the Asian population (11/15 cases), as well as in children and young adults (median age, 12.7 years; range, $0-45$ years); with the exception of a recently reported case of a 45 -year-old patient who complained of chronic diarrhea (4). There also appears to be a predilection for males (male to female ratio,11:6). Our group also revealed that the most commonly involved sites are the liver, spleen, lymph node and bone marrow, and the main clinical presentations are hepatosplenomegaly, fever and pancytopenia. Finally, we identified that almost all cases have an aggressive clinical course, which results in mortality (2,4-12).

Ohshima et al categorized EBV-associated T/NK-cell LPD in children and young adults into the following groups; A1 (polymorphic and polyclonal), A2 (polymorphic and generally monoclonal), A3 (monomorphic and monoclonal proliferation of $\mathrm{T}$ or NK-cell origin) and B (monomorphic and monoclonal T-cell LPD with an aggressive clinical course) (13). Group B is equivalent to systemic EBV-positive T-cell LPD of childhood according to the WHO classification, and corresponds to the case presented in this study (13).

Cytological atypia of this disease is minimal $(1,2,12)$ and has been demonstrated to delay diagnosis (12). In the present case, cytological atypia of the proliferative lymphocytes was minimal; however, double staining for EBER1 and CD3 or CD8 was useful for diagnosing systemic EBV-positive T-cell LPD of childhood. The cytological features of the atypical lymphocytes in the peripheral blood smear were also analyzed in this case report, and it was identified that the features observed in the present case were indistinguishable from those of infectious mononucleosis (14).

In conclusion, we reviewed the clinicopathological features of systemic EBV-positive T-cell LPD of childhood following acute EBV infection in order to broaden our knowledge of this disease and facilitate diagnosis. Cytological atypia of neoplastic cells in this disease is minimal; however, double staining for EBER1 and CD3 or CD8 is useful for diagnosis. Furthermore, the cytomorphological features of atypical lymphocytes in the peripheral blood are indistinguishable from those of infectous mononucleosis. Since the clinical course of systemic EBV-positive T-cell LPD of childhood is aggressive, further studies are required to clarify early and accurate diagnostic and therapeutic strategies for this disease.

\section{References}

1. Quintanilla-Martinez L, Kimura H and Jaffe ES: EBV-positive T-cell lymphoproliferative disorders of childhood. In: WHO Classification of Tumours of Haematopoietic and Lymphoid Tissues. Swerdlow SH, Campo E, Harris NL, Jaffe ES, Pileri SA, Stein H, Thiele J and Vardiman JW (eds). 4th edition. IARC Press, Lyon, pp278-280, 2008.

2. Quintanilla-Martinez L, Kumar S, Fend F, et al: Fulminant EBV(+) T-cell lymphoproliferative disorder following acute/ chronic EBV infection: a distinct clinicopathologic syndrome. Blood 96: 443-451, 2000.

3. Cohen JI, Kimura H, Nakamura S, Ko YH and Jaffe ES: Epstein-Barr virus-associated lymphoproliferative disease in non-immunocompromised hosts: a status report and summary of an international meeting, 8-9 September 2008. Ann Oncol 20: 1472-1482, 2009.

4. Su IJ, Lin KH, Chen CJ, et al: Epstein-Barr virus-associated peripheral T-cell lymphoma of activated CD8 phenotype. Cancer 66: 2557-2562, 1990.

5. Mori M, Kurozumi H, Akagi K, Tanaka Y, Imai S and Osato T: Monoclonal proliferation of $\mathrm{T}$ cells containing Epstein-Barr virus in fatal mononucleosis. N Eng J Med 327: 58, 1992.

6. Gaillard F, Mechinaud-Lacroix F, Papin S, et al: Primary Epstein-Barr virus infection with clonal T-cell lymphoproliferation. Am J Clin Pathol 98: 324-333, 1992.

7. Chan LC, Srivastava G, Pittaluga S, Kwong YL, Liu HW and Yuen HL: Detection of clonal Epstein-Barr virus in malignant proliferation of peripheral blood $\mathrm{CD}^{+}{ }^{+} \mathrm{CD} 8{ }^{+} \mathrm{T}$ cells. Leukemia 6 : 952-956, 1992.

8. Craig FE, Clare CN, Sklar JL and Banks PM: T-cell lymphoma and the virus-associated hemophagocytic syndrome. Am J Clin Pathol 97: 189-194, 1992.

9. Tazawa Y, Nishinomiya F, Noguchi H, et al: A case of fatal infectious mononucleosis presenting with fulminant hepatic failure associated with an extensive CD8-positive lymphocyte infiltration in the liver. Hum Pathol 24: 1135-1139, 1993.

10. Noma T, Kou K, Yoshizawa I, et al: Monoclonal proliferation of Epstein-Barr virus-infected T-cells in a patient with virusassociated haemophagocytic syndrome. Eur J Pediatr 153: 734-738, 1994.

11. Kawaguchi $\mathrm{H}$, Miyashita $\mathrm{T}$, Herbst $\mathrm{H}$, et al: Epstein-Barr virus-infected T lymphocytes in Epstein-Barr virus-associated hemophagocytic syndrome. J Clin Invest 92: 1444-1450, 1993.

12. Abdul-Ghafar J, Kim JW, Park KH and Cho MY: Fulminant Epstein-Barr virus-associated T-cell lymphoproliferative disorder in an immunocompetent middle-aged man presenting with chronic diarrhea and gastrointestinal bleeding. J Korean Med Sci 26: 1103-1107, 2011.

13. Ohshima K, Kimura H, Yoshino T, et al: Proposed categorization of pathological states of EBV-associated T/natural killer-cell lymphoproliferative disorder (LPD) in children and young adults: overlap with chronic active EBV infection and infantile fulminant EBV T-LPD. Pathol Int 58: 209-217, 2008.

14. Foucar K, Viswanatha DS and Wilson CA: Infectious mononucleosis (Epstein-Barr virus). In: Non-Neoplastic Disorders of Bone Marrow. Foucar K, Viswanatha DS and Wilson CA (eds). ARP Press, Washington DC, pp338-341, 2008. 